\title{
Analisis Faktor yang Berhubungan dengan Pemberian Susu Formula pada Bayi 0-6 Bulan
}

\author{
Rafika Oktova \\ Program Studi D-III Kebidanan STIKes Payung Negeri Pekanbaru \\ Email: rafikamkeb@gmail.com
}

\begin{abstract}
Analysis Related Factors With Formula Milk Feeding to Infant of 0-6 Months. Kinds of food pre-lacteal most given to the newborn are the formula milk of 79,8\%, honey $14,3 \%$ and the water white $13,2 \%$ which includes milk non-formula, honey, water sugar, water tajin, banana smooth, coffee, tea sweetened, white water, rice smooth, pulp smooth (The Departement of Health, 2014\&2015). The percentage of the scope of the lowest breastfeeding exclusive is at Rumbai Pesisir Health Center that is about 37,27\%. Research purposes were to know factor relating to the formula milk in infants age 0-6 month in Rumbai Pesisir Public Health Center Pekanbaru. The research was analytic design cross-sectional. The population of all the mother who the baby is 6-0 months was 1135 people. Samples were taken with accidental of sampling, as much as 92 people. Data analyzed by test chi-square $(\alpha<0,05)$. The results of statistical tests chisquare show that there is the correlation between knowledge, work and source of information by the formula milk feeding and there was no correlation between education with a formula milk feeding. Expected health workers to increase knowledge people such providing information of directives to the public about the formula milk influence in infants age 0-6 months.
\end{abstract}

Keywords: Knowledge, Education, Work, Source of information, Formula milk feeding

\begin{abstract}
Abstrak: Analisis Faktor yang Berhubungan dengan Pemberian Susu Formula pada Bayi Usia 0-6 Bulan. Jenis makanan prelakteal yang paling banyak diberikan kepada bayi baru lahir yaitu susu formula sebesar $79,8 \%$, madu $14,3 \%$, dan air putih $13,2 \%$ yang meliputi susu non formula, madu, air gula, air tajin, pisang halus, kopi, teh manis, air putih, nasi halus, bubur halus. Pemberian susu formula atau tambahan ASI yang terlalu dini dapat menganggu pemberian ASI ekslusif serta meningkatkan angka kesakitan morbiditas (Kemenkes RI, 2014\& 2015). Persentase cakupan pemberian ASI eksklusif terendah adalah di Puskesmas Rumbai Pesisir yaitu sebanyak $37,27 \%$. Tujuan penelitian untuk mengetahui faktor-faktor yang berhubungan dengan pemberian susu formula pada bayi usia 0-6 bulan di Puskesmas Rumbai Pesisir Pekanbaru. Penelitian ini adalah analitik desain cross sectional. Populasi penelitian adalah seluruh ibu yang mempunyai bayi 0-6 bulan berjumlah 1135 orang. Sampel berjumlah 92 orang diambil secara accidental sampling. Analisis data dengan uji chi-square $(\alpha<0,05)$. Hasil uji statistik chi-square menunjukkan bahwa terdapat hubungan antara pengetahuan, pekerjaan dan sumber informasi dengan pemberian susu formula dan tidak terdapat hubungan antara pendidikan dengan pemberian susu formula. Diharapkan tenaga kesehatan untuk meningkatkan pengetahuan masyarakat dengan cara memberikan penyuluhan atau pengarahan kepada masyarakat tentang pengaruh pemberian susu formula pada bayi usia 0-6 bulan.
\end{abstract}

Kata kunci: Pengetahuan, Pendidikan, Pekerjaan, Sumber informasi, Susu formula

Menurut Kemenkes RI (2014), secara nasional cakupan pemberian ASI ekslusif pada bayi $0-6$ bulan berfluaktif dan belum mencapai target nasional $80 \%$, yaitu tahun 2012 sebesar 46,2\%, tahun 2013 sebesar $54,3 \%$ dan tahun 2014 sebesar 52,3\%. Jenis makanan prelakteal yang paling banyak diberikan kepada bayi baru lahir yaitu susu formula sebesar $79,8 \%$, madu $14,3 \%$, dan air putih 13,2\% yang meliputi susu non formula, madu, air gula, air tajin, pisang halus, kopi, teh manis, air putih, nasi halus, bubur halus. Makanan prelakteal ini sangat berbahaya jika diberikan terlalu dini kepada bayi karena tidak mengandung enzim sehingga penyerapan pada makanan akan tergantung pada enzim yang terdapat di usus bayi. Menurut Kemenkes RI (2015), pemberian susu formula atau tambahan ASI yang terlalu dini dapat menganggu pemberian ASI ekslusif serta meningkatkan angka kesakitan (morbiditas).

Hasil penelitian Elisabeth (2006, dalam Ariani 2009) bayi yang tidak diberikan ASI secara eksklusif selama 6 bulan lebih rentan pada penyakit-penyakit yaitu sekitar $100 \%$ lebih rentan menderita diare, sekitar $60 \%$ lebih rentan menderita infeksi telinga, sekitar $40 \%$ lebih 
rentan menderita kencing manis/ diabetes tipe 1, sekitar 30\% lebih rentan menderita leukemia dan 25\% lebih rentan obesitas/ kegemukan. Menurut M. DHS (2013), menunjukkan bahwa kurang 1 dari 3 bayi di bawah usia 6 bulan diberi ASI eksklusif. Oleh karena itu, sebagian besar bayi di Indonesia tidak mendapatkan manfaat ASI terkait dengan gizi dan perlindungan terhadap penyakit.

Pemberian susu formula pada bayi sangat berbahaya karena dapat mengantikan kolostrum sebagai makanan bayi yang paling awal sehingga bayi mungkin saja terkena diare, septisema dan meningitis, serta mungkin bayi akan menderita intoleransi terhadap protein di dalam susu formula sehingga sering menimbul alergi terhadap bayi. Jenis makanan prelakteal yang diberikan cukup beragam antar daerah tergantung kebiasaan di daerah tersebut (Kemenkes RI, 2014).

Berdasarkan survei awal, data yang diperoleh dari Dinas Kesehatan Kota Pekanbaru tahun 2015, persentase cakupan ASI ekslusif di Kota Pekanbaru sebesar $55.22 \%$, hal ini berarti belum mencapai target nasional yaitu $80 \%$. Persentase cakupan pemberian ASI eksklusif terendah adalah di Puskesmas Rumbai Pesisir Pekanbaru yaitu sebesar $37,27 \%$ dari 20 puskesmas yang ada di Kota Pekanbaru.

Tujuan penelitian untuk menganalisis faktorfaktor yang berhubungan dengan pemberian susu formula pada bayi usia 0-6 bulan.

\section{METODE}

Jenis penelitian analitik dengan desain cross sectional. Penelitian dilakukan pada bulan Juni-Juli 2017 di Puskesmas Rumbai Pesisir Pekanbaru. Populasi dalam penelitian ini adalah seluruh ibu yang mempunyai bayi usia $0-6$ bulan di Puskesmas Rumbai PesisirPekanbaru periode Januari-Desember 2015 berjumlah 1135 orang. Jumlah sampel penelitian yaitu 92 orang yang diambil secara accidental sampling. Variabel Independen dalam penelitian ini adalah faktor pengetahuan, faktor pendidikan, faktor pekerjaan dan faktor sumber informasi. Variabel dependen adalah pemberian Susu Formula pada bayi usia 06 bulan. Alat pengumpul data yaitu kuesioner. Pengolahan data dilakukan dengan proses editing, coding, processing dan cleaning. Analisis univariate untuk melihat distribusi frekuensi dengan menggunakan rumus persentase. Analisis bivariate untuk mengetahui ada atau tidak hubungan faktor-faktor pemberian Susu Formula pada bayi usia 0-6 bulan. Uji statistik yang digunakan adalah chi-square dan menilai Odds Ratio (OR).

\section{HASIL}

\section{Karakteristik Responden}

Tabel 1. Distribusi Frekuensi Karakteristik Responden

\begin{tabular}{lrr}
\hline Variabel Penelitian & \multicolumn{1}{c}{ Frek } & \multicolumn{1}{c}{$\%$} \\
\hline Pengetahuan & & \\
\hline Baik & 20 & 21,7 \\
Kurang & 72 & 78,3 \\
\hline Pendidikan & & \\
\hline Tinggi & 9 & 9,8 \\
Rendah & 83 & 90,2 \\
\hline Pekerjaan & & \\
\hline Bekerja & 20 & 21,7 \\
Tidak Bekerja & 72 & 78,3 \\
\hline Sumber Informasi & & \\
\hline Tenakes & 27 & 29,3 \\
Non-Tenakes & 65 & 70,7 \\
\hline Pemberian Susu Formula & & \\
\hline Ya & 64 & 69,6 \\
Tidak & 30 & 30,4 \\
\hline Total & 92 & 100,0 \\
\hline
\end{tabular}

Pada Tabel 1 menunjukkan bahwa mayoritas responden berpengetahuan kurang sebanyak 72 orang $(78,3 \%)$, mayoritas berpendidikan rendah sebanyak 83 orang $(90,2 \%)$, mayoritas pekerjaan responden adalah tidak bekerja sebanyak 72 orang $(78,3 \%)$, mayoritas sumber informasi diperoleh responden adalah dari non-tenaga kesehatan sebanyak 65 orang $(70,7 \%)$ dan mayoritas responden memberikan susu formula pada bayi usia 0-6 bulan sebanyak 64 orang $(69,6 \%)$.

Tabel 2. Hubungan Pengetahuan dengan Pemberian Susu Formula pada Bayi Usia 0-6 Bulan

\begin{tabular}{|c|c|c|c|c|c|c|}
\hline \multirow{3}{*}{$\begin{array}{c}\text { Variabel } \\
\text { Penelitian }\end{array}$} & \multicolumn{4}{|c|}{$\begin{array}{c}\text { Pemberian } \\
\text { Susu Formula }\end{array}$} & \multirow{2}{*}{\multicolumn{2}{|c|}{ Total }} \\
\hline & \multicolumn{2}{|c|}{ Ya } & \multicolumn{2}{|c|}{ Tidak } & & \\
\hline & $\mathbf{n}$ & $\%$ & $\mathbf{n}$ & $\%$ & $\mathbf{n}$ & $\%$ \\
\hline \multicolumn{7}{|l|}{ Pengetahuan } \\
\hline Baik & 2 & 10 & 18 & 90 & 20 & 100 \\
\hline Kurang & 62 & 86,1 & 10 & 13,9 & 72 & 100 \\
\hline Jumlah & 64 & 69,6 & 28 & 30,4 & 92 & 100 \\
\hline p value & \multicolumn{6}{|c|}{$0,004(\mathrm{p}<0,05)$} \\
\hline $\mathrm{OR}(95 \% \mathrm{CI})$ & \multicolumn{6}{|c|}{$0,018(0,004-0,089)$} \\
\hline
\end{tabular}

Pada Tabel 2 menunjukkan hasil uji statistik diperoleh nilai $p$-value $(0,004<\alpha 0,05)$, artinya ada hubungan pengetahuan responden dengan pemberian susu formula pada bayi 0-6 
bulan. Nilai $(\mathrm{OR}=0,018)$ artinya responden yang berpengetahuan baik mempunyai peluang $1 / 0,018$ atau 55,6 kali mencegah memberikan susu formula pada bayi usia $0-6$ bulan dibanding responden yang berpengetahuan kurang.

Tabel 3. Hubungan Pendidikan Dengan Pemberian Susu Formula Pada Bayi Usia 0-6 Bulan

\begin{tabular}{|c|c|c|c|c|c|c|}
\hline \multirow{3}{*}{$\begin{array}{c}\text { Variabel } \\
\text { Penelitian }\end{array}$} & \multicolumn{4}{|c|}{$\begin{array}{c}\text { Pemberian } \\
\text { Susu Formula }\end{array}$} & \multirow{2}{*}{\multicolumn{2}{|c|}{ Total }} \\
\hline & \multicolumn{2}{|c|}{ Ya } & \multicolumn{2}{|c|}{ Tidak } & & \\
\hline & n & $\%$ & $\mathbf{n}$ & $\%$ & $\mathbf{n}$ & $\%$ \\
\hline \multicolumn{7}{|l|}{ Pendidikan } \\
\hline Tinggi & 7 & 77,8 & 2 & 22,2 & 9 & 100 \\
\hline Rendah & 57 & 68,7 & 26 & 31,3 & 83 & 100 \\
\hline Jumlah & 64 & 69,6 & 28 & 30,4 & 92 & 100 \\
\hline$p$ value & \multicolumn{4}{|c|}{$0,573(\mathrm{p}>0,05)$} & & \\
\hline OR $(95 \% \mathrm{CI})$ & \multicolumn{4}{|c|}{$1,596(0,310-8,218)$} & & \\
\hline
\end{tabular}

Pada tabel 3 menunjukkan bahwa hasil uji statistik diperoleh nilai $p$-value $(0,573>\alpha 0,05)$. Hal ini berarti tidak ada hubungan antara pendidikan responden dengan pemberian susu formula pada bayi usia 0-6 bulan. Nilai $(\mathrm{OR}=1,596)$ artinya responden yang pendidikan rendah beresiko 1,596 kali memberikan susu formula pada bayi usia 0-6 bulan dibanding responden yang pendidikan tinggi.

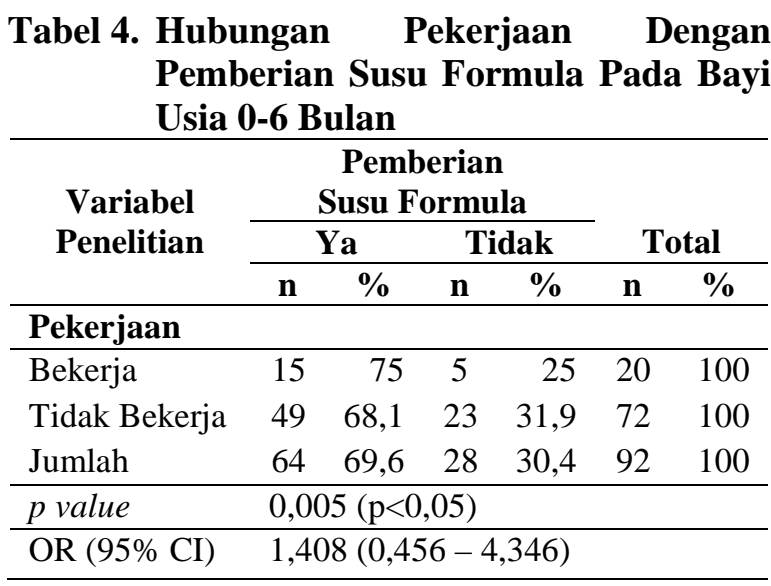

Pada Tabel 4 menunjukkan bahwa hasil uji statistik diperoleh nilai p-value $(0,005<\alpha \quad 0,05)$, artinya ada hubungan antara pekerjaan responden dengan pemberian susu formula pada bayi usia 06 bulan. Nilai $(\mathrm{OR}=1,408)$ artinya responden yang bekerja beresiko 1,408 kali untuk memberikan susu formula pada bayi usia 0-6 bulan dibanding responden yang tidak bekerja.
Tabel 5. Hubungan Sumber Informasi Dengan Pemberian Susu Formula Pada Bayi Usia 0-6 Bulan

Pemberian

\begin{tabular}{lcccccc}
\hline \multirow{2}{*}{$\begin{array}{l}\text { Variabel } \\
\text { Penelitian }\end{array}$} & \multicolumn{4}{c}{ Pemberian } & & \\
\cline { 2 - 5 } & \multicolumn{2}{c}{ Susu Formula } & \multicolumn{2}{c}{ Tidak } & \multicolumn{2}{c}{ Total } \\
\cline { 2 - 5 } & $\mathbf{n}$ & \% & n & \% & n & \% \\
\hline Sumber Informasi & & & & & \\
\hline $\begin{array}{l}\text { Tenaga } \\
\text { Kesehatan }\end{array}$ & 14 & 51,9 & 13 & 48,1 & 27 & 100 \\
$\begin{array}{l}\text { Non-Tenaga } \\
\text { Kesehatan }\end{array}$ & 50 & 76,9 & 15 & 23,1 & 65 & 100 \\
Jumlah & 64 & 69,6 & 28 & 30,4 & 92 & 100 \\
\hline$p$ value & $0,017(\mathrm{p}<0,05)$ & & & \\
\hline OR (95\% CI) & $0,323(0,125-0,836)$ & & \\
\hline
\end{tabular}

Pada Tabel 5 menunjukkan bahwa hasil uji statistik diperoleh nilai $p$-value $(0,017<\alpha 0,05)$, artinya ada hubungan antara sumber informasi yang diperoleh responden dengan pemberian susu formula pada bayi usia $0-6$ bulan. Nilai $(\mathrm{OR}=0,323)$ artinya responden yang memperoleh informasi dari tenaga kesehatan mempunyai peluang $1 / 0,323$ atau 3,1 kali mencegah memberikan susu formula pada bayi usia 0-6 bulan dibanding responden yang memperoleh informasi dari non-tenaga kesehatan.

\section{PEMBAHASAN}

\section{Pengetahuan}

Penelitian yang dilakukan pada 92 responden di Puskesmas Rumbai Pesisir Pekanbaru tentang faktor-faktor yang berhubungan dengan pemberian susu formula pada bayi usia 0-6 bulan diperoleh hasil yaitu terdapat hubungan yang bermakna antara pengetahuan responden dengan pemberian susu formula pada bayi usia 0-6 bulan.

Hasil penelitian ini sejalan dengan penelitian Rombot, Kandou \& Ratag (2013) tentang Faktor-faktor yang berhubungan dengan pemberian susu formula pada bayi usia 0-6 bulan di Wilayah Kerja Puskesmas Molompar Tombatu Timur Minahasa Tenggara diperoleh nilai $p<0,027$ artinya ada hubungan pengetahuan ibu dengan pemberian susu formula pada bayi usia $<6$ bulan. Penelitian yang sama oleh Setiyani, Indrawati dan Sumini (2014) tentang Hubungan Pengetahuan Ibu tentang Pemberian Susu Formula dengan Praktek Pemberian Susu Formula pada Bayi 7-12 Bulan di Puskesmas Ngemplak Simongan Semarang menggunakan uji Chi Square diperoleh hasil $\mathrm{X}^{2}$ hitung yaitu $8,584 \geq$ $\mathrm{X}_{\text {tabel }}^{2}$ yaitu 3,841. Dengan demikian, Ha diterima yang berarti terdapat hubungan antara 
pengetahuan ibu tentang pemberian susu formula dengan praktek pemberian susu formula. Hasil penelitian ini menunjukkan bahwa pengetahuan sangat mempengaruhi adanya perilaku positif, karena perilaku yang tidak didasari oleh pengetahuan sifatnya tidak langgeng. Dengan demikian responden yang berpengetahuan kurang tidak dapat mempraktekkan pemberian susu formula dengan baik.

Menurut Rosita (2008) faktor pengetahuan ibu yang kurang sering membuat ibu memilih menggunakan susuformula daripada memberikan ASI pada bayinya. Misalnya pada saat ibu sakit influenza atau batuk ibu kadang takut menularkan penyakitnya pada bayi, sehingga ibu tidak mau menyusui. Jika ibu berhenti menyusui dan menggantinya dengan susu formula justru resiko untuk tertular penyakit akan lebih besar.

Hasil penelitian diperoleh mayoritas pengetahuan responden tentang pemberian susu formula adalah kurang dan terdapat hubungan antara pengetahuan dengan pemberian susu formula. Responden yang berpengetahuan baik mempunyai peluang mencegahmemberikan susu formula kepada bayi usia 0-6 bulan dibandingkan dengan responden yang berpengetahuan kurang. Hal ini berarti semakin kurang pengetahuan seseorang tentang pemberian susu formula maka akan semakin banyak yang memberikan susu formula yang tidak tepat waktu sehingga secara langsung akan menurunkan cakupan ASI eksklusif dan meningkatkan angka kesakitan bayi.

\section{Pendidikan}

Penelitian yang dilakukan pada 92 responden di Puskesmas Rumbai Pesisir Pekanbaru tentang faktor-faktor yang berhubungan dengan pemberian susu formula pada bayi usia 0-6 bulan diperoleh hasil yaitu tidak terdapat hubungan yang bermakna antara pendidikan responden dengan pemberian susu formula pada bayi usia 0-6 bulan.

Hasil penelitian ini sama dengan penelitian yang dilakukan oleh Rau (2016) tentang Hubungan Karakteristik Ibu dengan Pemberian Susu Formula pada Bayi Usia 0-6 Bulan Di Wilayah Kerja Puskesmas Mabelopura Palu diperoleh nilai $p<0,710$ artinya tidak ada hubungan tingkat pendidikan ibu dengan pemberian susu formula pada bayi usia $<6$ bulan.

Menurut Roesli (2009) menyatakan bahwa tingkat pendidikan ibu yang rendah mengakibatkan kurangnya pengetahuan ibu dalam menghadapi masalah, terutama dalam pemberian ASI ekslusif, sedangkan ibu-ibu yang memiliki tingkat pendidikan yang tinggi umumnya terbuka dalam menerima perubahan hal-hal yang baru guna memilihara kesehatan. Hal yang sama dikemukakan oleh Ibrahim (2014, dalam Oktova 2017) bahwa ibu yang berpendidikan rendah akan lebih mudah menerima pesan atau informasi yang disampaikan orang lain karena berdasarkan pengalaman dan budaya yang ada pada masyarakat setempat.

Teori yang sama dikemukakan oleh Arifin (2004 dalam Puspitasari 2012), bahwa pendidikan menjadi tolak ukur yang penting dalam mempengaruhi pola pikir ibu untuk menentukan tindakan baik yang menguntungkan atau tidak. Dimana seseorang yang berpendidikan tinggi akan lebih bisa menerima alasan untuk memberikan ASI eksklusif karena pola pikirnya yang lebih realistis dibandingkan yang tingkat pendidikan rendah. Hal ini membuktikan bahwa faktor pendidikan tidak bisa menjadi tolak ukur untuk perubahan perilaku karena masih banyak faktor lain yaitu faktor pekerjaan, penghasilan/ sosial ekonomi, pengetahuan tentang ASI, budaya, psikologis, promosi susu formula, dan kesehatan ibu.

Hasil penelitian yang telah dilakukan diperoleh mayoritas responden berpendidikan rendah, secara statistik tidak ada hubungan antara faktor pendidikan dengan pemberian susu formula pada bayi usia 0-6 bulan. Responden yang berpendidikan rendah beresiko memberikan susu formula kepada bayi usia 0-6 bulan dibandingkan dengan responden yang berpendidikan tinggi. Hal ini berarti bahwa prilaku pemberian susu formula pada bayi usia 0-6 bulan dipengaruhi oleh banyak faktor seperti lingkungan, persepsi ibu tentang iklan susu formula di media massa, dan sebagainya. Seseorang yang berpendidikan rendah tidak selalu cenderung memberikan susu formula kepada bayi usia 0-6 bulan.

\section{Pekerjaan}

Penelitian yang telah dilakukan pada 92 responden di Puskesmas Rumbai Pesisir Pekanbaru tentang faktor-faktor yang berhubungan dengan pemberian susu formula pada bayi usia 0-6 bulan diperoleh hasil yaitu terdapat hubungan yang bermakna antara pekerjaan responden dengan pemberian susu formula pada bayi usia 0-6 bulan.

Penelitian ini sejalan dengan penelitian Wayuni (2014) tentang Faktor-Faktor Yang Berhubungan Dengan Pemberian Susu Formula Pada Bayi Usia 0-6 Bulan Di Desa Wonosari Kecamatan Ngoro Mojokerto diperoleh bahwa ada hubungan antara faktor pekerjaan dengan pemberian susu formula ( $p$-value $<0,05)$.

Hasil penelitian yang telah dilakukan diperoleh bahwa mayoritas pekerjaan responden 
adalah tidak bekerja, secara statistik terdapat hubungan pekerjaan dengan pemberian susu formula. Responden yang bekerja beresiko untuk memberikan susu formula kepada bayi usia 0-6 bulan dibandingkan dengan responden yang tidak bekerja. Status pekerjaan ibumempengaruhi prilaku pemberian susu formula pada bayi usia 0 6 bulan.

\section{Sumber Informasi}

Berdasarkan hasil penelitian yang dilakukan pada 92 responden di Puskesmas Rumbai Pesisir Pekanbaru faktor-faktor yang berhubungan dengan pemberian susu formula pada bayi usia 0-6 bulan diperoleh hasil yaitu tidak terdapat hubungan yang bermakna antara sumber informasi responden dengan pemberian susu formula pada bayi usia 0-6 bulan.

Penelitian ini sejalan dengan penelitian Triana. H (2012) tentang Faktor-Faktor Yang Berhubungan Dengan Pemberian Susu Formula Pada Bayi Usia 0-6 Bulan Di Kelurahan Helvetia Timurdiperoleh hasil uji statistik chi square di peroleh $p$-value $=0,045<0,05$ artinya ada hubungan antara media informasi dengan pemberian susu formula.

Penelitian ini sejalan penelitian Fitriana, Rahayuning dan Nugraheni (2014) tentang Faktor-Faktor Yang Melatarbelakangi Ibu Dalam Pemberian Susu Formula Pada Bayi Usia 0-6 Bulan Di Wilayah Kerja Puskesmas Rowosari Kecamatan Tembalang Semarang bahwa susu formula banyak dijumpai di tempat atau toko yang menjual susu formula bayi dengan berbagai merek. Mulai dari harga yang bisa dijangkau sampai harga yang mahal tentu dengan imingiming yang menarik perhatian. Bahkan di mediamedia promosi susu formula pun selalu gencar dibandingkan dengan promosi menyusui secara eksklusif. Iming-iming merek susu tertentu yang isinya menyamakan dengan ASI, misalnya jika bayi diberikan merek tertentu maka perkembangan dan pertumbuhannya bagus, aktif, dan cerdas.

Hasil penelitian mayoritas sumber informasi tentang susu formula yang diperoleh responden adalah dari non tenaga kesehatan, secara statistik terdapat hubungan antara faktor sumber informasi dengan pemberian susu formulapada bayi usia 0-6 bulan. Responden yang memperoleh informasi dari tenaga kesehatan mempunyai peluang untuk mencegah memberikan susu formula kepada bayi usia 0-6 bulan dibandingkan dengan responden yang memperoleh informasi dari non-tenaga kesehatan. Sumber informasi yang diperoleh ibu mempengaruhi praktek pemberian susu formula pada bayi usia 0-6 bulan.

\section{SIMPULAN}

1. Distribusi frekuensi ibu yang mempunyai bayi 0-6 bulan di Wilayah Kerja Puskesmas Rumbai Pesisir Pekanbaru periode JanuariDesember 2015 mayoritas memiliki pengetahuan kurang, mayoritas memiliki tingkat pendidikan rendah, mayoritas tidak bekerja dan sumber informasi tentang susu formula diperoleh dari non tenaga kesehatan.

2. Terdapat hubungan antara pengetahuan, pekerjaan dan sumber informasi dengan pemberian susu formula pada bayi usia 0-6 bulan.

3. Tidak terdapat hubungan antara tingkat pendidikan dengan pemberian susu formula pada bayi usia $0-6$ bulan.

\section{SARAN}

1. Bagi tenaga kesehatan diharapkan hasil penelitian ini dapat dijadikan salah satu bahan pertimbangan dan informasi untuk meningkatkan pengetahuan masyarakat dengan cara memberikan penyuluhan atau pengarahan kepada masyarakat tentang pengaruh pemberian susu formula pada bayi usia 0-6 bulan.

2. Bagi peneliti selanjutnya diharapkan hasil penelitian ini dapat digunakan sebagai dasat untuk penelitian selanjutnya tentang variabel lain yang berhubungan dengan pemberian susu formula pada bayi usia 0-6 bulan seperti persepsi ibu, iklan susu formula, perilaku.

\section{DAFTAR PUSTAKA}

Ariani. 2009. Ibu Susui Aku. Cetakan I. Bandung: Khazanah Intelektual.

Dinkes Kota Pekanbaru. 2015. Cakupan Pemberian ASI Eksklusif.
Fitriana, Rahayuning dan Nugraheni. 2015. Faktor-Faktor Yang Melatarbelakangi Ibu Dalam Pemberian Susu Formula Pada Bayi Usia 0-6 Bulan di Wilayah Kerja 
Puskesmas Rowosari Kecamatan Tembalang Semarang. Jurnal Kesehatan Masyarakat, Vol.3, No. 2.

Kemenkes RI. 2014. Pusat Data dan Informasi 2014: Situasi dan Analisis ASI Eksklusif. http://www.depkes.go.id/resources/ download/pusdatin/infodatin/infodatinasi.pdf (Diakses 3 Juni 2017).

Kemenkes RI. 2015. Profil Kesehatan Indonesia 2014: Pemberian ASI Eksklusif. www.depkes.go.id/resources/download/pu sdatin/profil-kesehatan-indonesia (Diakses 3 Juni 2017).

Rau, Muh. Jusman, Nikmah Utami Dewi, Mufydah. 2016. Hubungan Karakteristik Ibu dengan Pemberian Susu Formula pada Bayi Usia 0-6 Bulan Di Wilayah Kerja Puskesmas Mabelopura Palu. Preventif, Vol.7, No.2.

M. DHS. 2013. Survey Demografi Kesehatan Indoensia 2012: Perbedaan Demografis pada Kematian Bayi dan Anak. http://chnrl.org/pelatihan-demografi (Diakses 4 Juni 2017).

Oktova, R. 2017. Determinan yang Berhubungan dengan Pemberian MP-ASI Dini pada Bayi Usia 0-6 Bulan. Jurnal Kesehatan, Vol. III No 1. http://ejurnal.poltekkestjk.ac.id/index.php/JK/article/view/396/37 0 (Diakses 22 Agustus 2017)

Puspitasari, Ririn Indrawati. 2012. Gambaran Faktor-Faktor Yang Mempengaruhi Pemberian Susu Formula Pada Ibu Yang Mempunyai Bayi Usia 0-6 Bulan. Jurnal Bidan Prada, Vol. 3, No. 1.

Roesli, U. 2009. Mengenal ASI Eksklusif. Revisi. Jakarta: Trumbus Agriwidya.

Rosita, Syarifah. 2008. ASI untuk Kecerdasan Bayi, Panduan Lengkap Ibu Menyusui. Yogyakarta: Ayyana.
Rombot Gabriella., Grace D. Kandou., Gustaaf A. E. Ratag. 2013. Faktor-faktor yang berhubungan dengan pemberian susu formula pada bayi usia 0-6 bulan di Wilayah Kerja Puskesmas Molompar Tombatu Timur Minahasa Tenggara. Jurnal Kedokteran Komunitas. Jurnal Kedokteran Komunitas dan Tropik, Vol. 1, No. 4, Desember 2013.

http://ejournal.unsrat.ac.id/index.php/JKK T/article/view/5325 (Diakses 20 Agustus 2017).

Setiyani, Indrawati dan Sumini. 2014. Hubungan Pengetahuan Ibu tentang Pemberian Susu Formula dengan Praktek Pemberian Susu Formula pada Bayi 7-12 Bulan di Puskesmas Ngemplak Simongan Semarang. Jurnal Abdi Husada. http://jurnal.abdihusada.ac.id/index.php/jur abdi/article/view/50 (Diakses 11 Agustus 2017).

Triana. H. 2012. Faktor-Faktor Yang Berhubungan Dengan Pemberian Susu Formula Pada Bayi Usia 0-6 Bulan Di Kelurahan Helvetia Timur. Tesis, Fakultas Kesehatan Masyarakat, Universitas Sumatera Utara.

http://repository.usu.ac.id/handle/1234567 89/34055 (Diakses 19 Agustus 2017).

Wayuni, Tri. 2014. Faktor-Faktor Yang Berhubungan Dengan Pemberian Susu Formula Pada Bayi Usia 0-6 Bulan Di Desa Wonosari Kecamatan Ngoro Mojokerto. Karya Tulis Ilmiah Kebidanan, Poltekkes Majapahit.

http://repository.poltekkesmajapahit.ac.id/i ndex.php/PUB-KEB/article/view/99/80 (Diakses 21 Agustus 2017). 